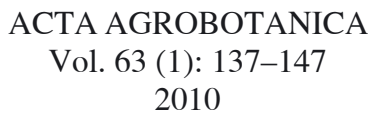

\title{
PATHOGENICITY OF Colletotrichum dematium (FR.) GROVE TO CARAWAY Carum carvi L.
}

\author{
Ewa Zalewska \\ Department of Phytopathology and Mycology, University of Life Sciences, \\ Leszczyńskiego 7, 20-069 Lublin, Poland \\ e-mail: ewa.zalewska@up.lublin.pl
}

Received: 8.02.2010

\begin{abstract}
The aim of present work was to determine pathogenicity of three Colletotrichum dematium isolates to caraway. The effect of post-culture liquids and water suspension of conidia on germination of caraway schizocarps was studied in laboratory conditions. The effect of $C$. dematium on shooting up and healthiness of the seedlings was carried out in the climatic chamber using the method with infested soil and solidified plaster of culture medium overgrown by the mycelium of the pathogen. The studied isolates of fungus made the germination of parts of tested schizocarps impossible. On the other hand, all isolates caused necrosis of germs and roots of the other germinated schizocarps. The method with Colletotrichum dematium post-culture liquids was recognized as the best to a fast estimation of pathogenicity of fungus to caraway. Based on the positive results of pathogenicity tests the studied isolates of $C$. dematium were recognized as pathogenic to caraway. Considering this fact and repeated frequency of isolation of the fungus from various organs of this plant (Machowicz-Stefaniak, 2010), C. dematium was recognized as a potentially pathogenic species to caraway.
\end{abstract}

Key words: Carum carvi, Colletotrichum dematium, pathogenicity

\section{INTRODUCTION}

Caraway (Carum carvi L.) affects various pathogenic microorganisms, especially fungi (Evenhuis et al. 1995; Gabler and Ehrig, 1999; Odstrčilova et al. 2002; Machowicz-Stefaniak and Zalewska, 2004; 2008; Bedlan, 2005; Zalewska, 2008; M achowicz-Stefaniak, 2010). The pathogenic and saprophytic isolates of fungi occurring on caraway can cause a decrease of the quantity and quality of the herb material (Machowicz-Stefaniak et al. 2003; Machowicz-Stefaniak and Zalewska, 2004; 2008). In Poland, the species Colletotrichum dematium (Fr.) Grove was isolated, for the first time in 2005 and in the subsequent years of study, i.e. in 2006 and 2007 it occurred with increasing frequency (Machowicz-Stefaniak, 2010). This fungus can colonize the tissues of numerous species of plants as secondary pathogen, and its pathogenic strains can cause anthracnose of plants in various geographical regions (Von Arx, 1957; Sutton, 1980; Farr et al. 1995; Y o shid a and Shirata, 1999; S h inde et al. 2003). C. dematium f. sp. spinacae has been noted since 1989 on spinach cultivated in USA, and pathogenic tests confirmed that it is the cause of spinach anthracnose (Cerkauskas and McDonald, 1991; C orrell et al. 1994). Similarly, the cultures of $C$. dematium obtained from spinach plants showed anthracnose symptoms in Austria in 2004, and pathogenicity of this fungus was confirmed experimentally (W a shington et al. 2006). Moreover, C. dematium was recognized as a cause of decline of the leaves of Japanese radish seedlings in Japan, although previously such symptoms of disease were attributed to other species of Colletotrichum genera (S a to et al. 2005). The information in literature suggests that the fungus is harmful especially in the early phases of plant development because it was the cause of post-emergence damping-off of beech (Fagus crenata) seedlings in Japan while in Bangladesh and India it significantly limited germination of soybean and chili seeds, respectively ( $\mathrm{S}$ a has hi et al. 1995; $\mathrm{Sh}$ ovan et al. 2008; $\mathrm{Padgh} \mathrm{an}$ and B elge, 2009). In addition, reports from literature show that the fungus $C$. dematium is also harmful to ornamental plants. The occurrence of fungus was observed, especially during very humid periods, on stems of catharanthus (Catharanthus roseus L.) in Florida, on the leaves of rhododendrons in Sweden and Latvia and on various plants from Amarylidaceae family in Cuba, as well as on the stems and 
on the leaves of caspia (Limonium bellidifolium) and German statice (Goniolimon tataricum) in Taiwan and Bulgaria. The positive effects of tests with artificial infection and reisolation of the pathogen cultures with the macroscopic and microscopic features corresponding to original cultures, confirmed its harmful effect (McMillan and Graves, 1996; Vinnere et al. 2002; B onilla-Bernal et al. 2003; Hong et al. 2006; B obe v et al. 2009).

In the absence of information about the occurrence of $C$. dematium on herbs in literature and in view of pathogenicity of fungus to caraway, the present research was carried out.

\section{MATERIAL AND METHODS}

Three isolates of $C$. dematium $\mathrm{K} 425, \mathrm{~K} 426$ and $\mathrm{K} 625$ randomly chosen from the population of fungus obtained in 2005-2007 as a result of a study on the diseases of caraway, were used in the present study (Machowicz-Stefaniak and Zalewska, 2008; M a c howicz-S te faniak, 2010), (Figs 1, $2,3)$. Samples of the sowing material of caraway taken for the study came from ordinary retail seed companies Commerce Dr. Eng. Wiesław Legutko Smolice near Kobylin.

The effects of post-culture liquids and water suspension of conidia of $C$. dematium on the germinating ability of caraway schizocarps and the effect of C. dematium on shooting and healthiness of seedlings using the method with infested soil and plaster of fungi colony were studied (M a ń ka, 1989; M a c howicz-Stefaniak et al. 2008).

With the aim of obtaining the post-culture liquids containing the mycelium, spores and metabolites of fungi, the studied isolates of fungus were cultivated in Erlenmeyer flasks $(250 \mathrm{ml})$ on liquid culture medium PDB Broth (Difco), at the temperature of $22^{\circ} \mathrm{C}$, in a thermostat for 8 days (M ishra and $\mathrm{Behr}$, 1976). The superficially disinfected schizocarps of caraway (Machowicz-Stefaniak and Zalew$\mathrm{s} \mathrm{k} \mathrm{a,2000)}$ were placed in sterile moist chambers on blotting paper soaked with $3 \mathrm{ml}$ of fungi post-culture liquids. The control consisted of schizocarps placed in sterile moist chambers on blotting paper soaked with $3 \mathrm{ml}$ of liquid culture medium PDB Broth. The prepared plates were placed in conditions enabling germination of schizocarps, i.e. in a thermostat without light, at the temperature of $25^{\circ} \mathrm{C}$. The blotting paper in moist chambers was wetted every second day with $1 \mathrm{ml}$ of post-culture liquids in the experimental combination and with sterile water in the control.

The infection material consisted of water suspension of the conidia with the density $3 \times 10^{6} \mathrm{co}-$ nidia $/ \mathrm{ml}$. The suspension was made from conidia obtained from one-spore cultures of the examined
Colletotrichum dematium isolates, growing on PDA medium, at the temperature $25^{\circ} \mathrm{C}$, in a thermostat without the access of light. A few drops of the preparation Filpon were added to the suspension of conidia ( $\mathrm{a}$ acicowa et al. 1992). The superficially disinfected schizocarps of caraway were singly soaked in a PDA agar medium with half reduced amount of agar and next in a suspension of conidia and then they were placed in sterile moist chambers. The control was the schizocarps soaked only in the same PDA medium and after then in sterile distilled water. In both variants of the experiment, a total of 800 schizocarps, i.e. 400 schizocarps for one variant (100 schizocarps per one isolate and to control) were taken.

Observations of germination were conducted every three days, i.e. after 3, 6 and 9 days. The numbers of schizocarps that had and had not germinated as well as the number of germs with necrosis was determined. The germs with necrosis and schizocarps that had not germinated were submitted to reisolation according to Koch`s postulates. The results obtained from recent observation were statistically analyzed using Tukey`s confidence intervals.

The single strain K 426 characterized with the highest pathogenicity in laboratory test was used in studies on the effect of $C$. dematium on emergencies and health of seedlings of caraway. The superficially disinfected schizocarps of caraway were sown into pots with $1 / 3$ their capacity of sterile compost soil mixed with quartz sand in the proportion $2: 1$, and next Noll's mixture ( $\mathrm{E} \mathrm{a} \mathrm{c} \mathrm{i} \mathrm{c} \mathrm{o} \mathrm{w} \mathrm{a,} \mathrm{1964)} \mathrm{with} \mathrm{an} \mathrm{addition}$ of $5 \%$ of the barley cereals and they were covered with a 0.3 to $0.5 \mathrm{~cm}$ layer of sterile compost soil. The control consisted of superficially disinfected schizocarps sown into the compost soil with an addition of 5\% of barley cereals. Totally, 200 schizocarps, i.e. 5 pots with 20 schizocarps in each were used for the experimental combination and in control (100 for isolate and 100 for the control). The prepared material was kept in a climatic chamber at the temperature of $20^{\circ}-22^{\circ} \mathrm{C}$ with the relative humidity at the level of $80-84 \%$. The soil moisture in pots was kept by watering every two days with sterile distillated water in quantities of $10 \mathrm{ml}$. The number of the obtained plants and plants with necrosis was determined after 6,10,14 and 21 days. Next, the plant material was reisolated according to Koch`s postulates. The results obtained in the last observation were statistically analyzed.

In the second part of the experiment on the effect of $C$. dematium on emergencies and healthiness of seedlings of caraway, infection with a plaster of solidified medium overgrown by the fungus mycelium was used (M a ń $\mathrm{k} \mathrm{a}, 1989$ ). The inoculums of the fungus consisted of 14-day-old colonies of chosen strain $\mathrm{K} 426$ growing on PDA medium at the temperature of $25^{\circ} \mathrm{C}$ (Figs 1,2,3). Plasters of the colonies were placed 
to pots filled to $3 / 4$ of their capacity with sterile compost soil mixed with quartz sand in a 2:1 proportion. Next, the germinating schizocarps of caraway were placed directly on the plaster fungus colony. To the studies were used only these germinating schizocarps without any lesions, and their length did not exceed $10 \mathrm{~mm}$. The shoots were obtained from superficially disinfected schizocarps of caraway, which germinated at the temperature of $22^{\circ} \mathrm{C}$ for 7 days. These germinating schizocarps in pots were covered with a thin layer of earlier used soil mixture ( $\mathrm{M}$ a ń $\mathrm{k} \mathrm{a}, 1989)$. The control consisted of pots where the germinated schizocarps were placed directly on a plasters of PDA medium. In the experimental combination and in control, totally 200 schizocarps, i.e. 5 pots with 20 schizocarps in each were used. The observations were conducted for 14 days and after then reisolation of the fungus from the obtained seedlings was performed.

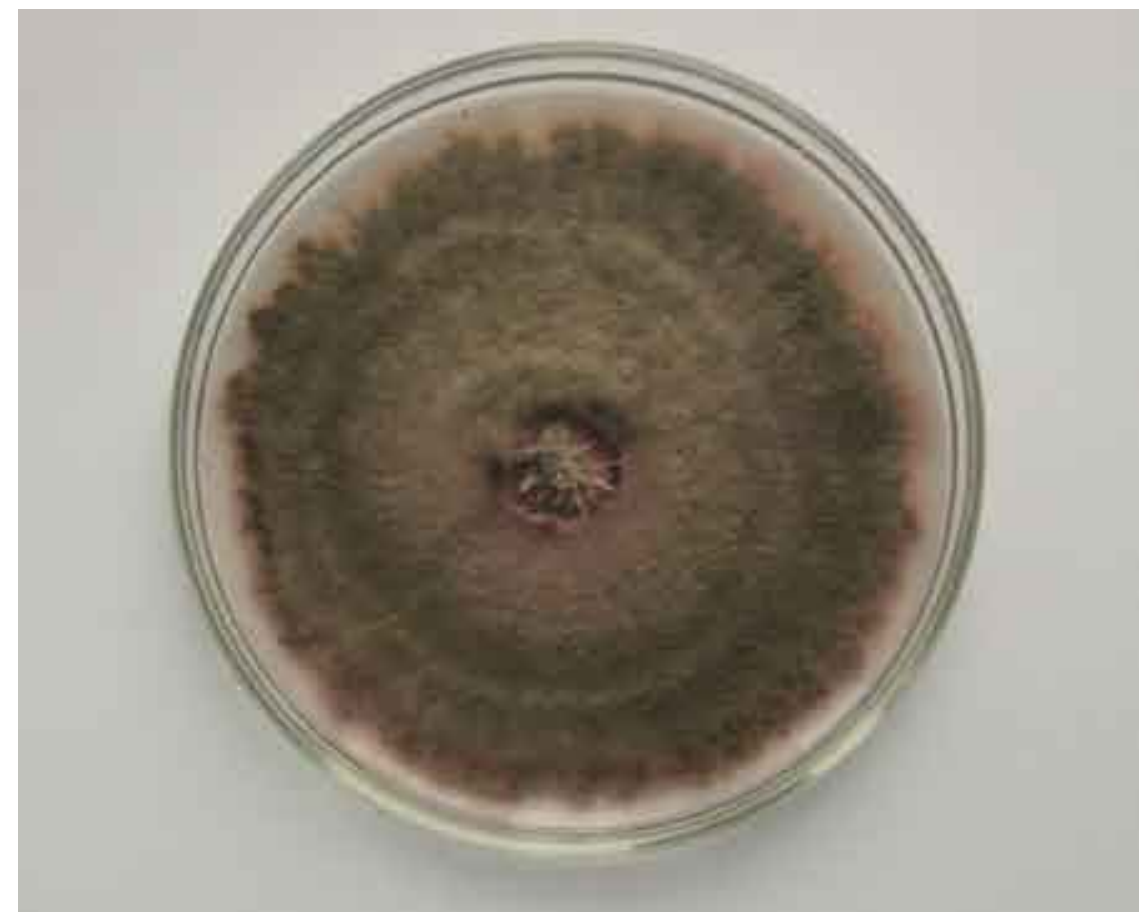

Fig. 1. 14-day old colony of Colletotrichum dematium isolate K 426 on PDA - photo E. Zalewska

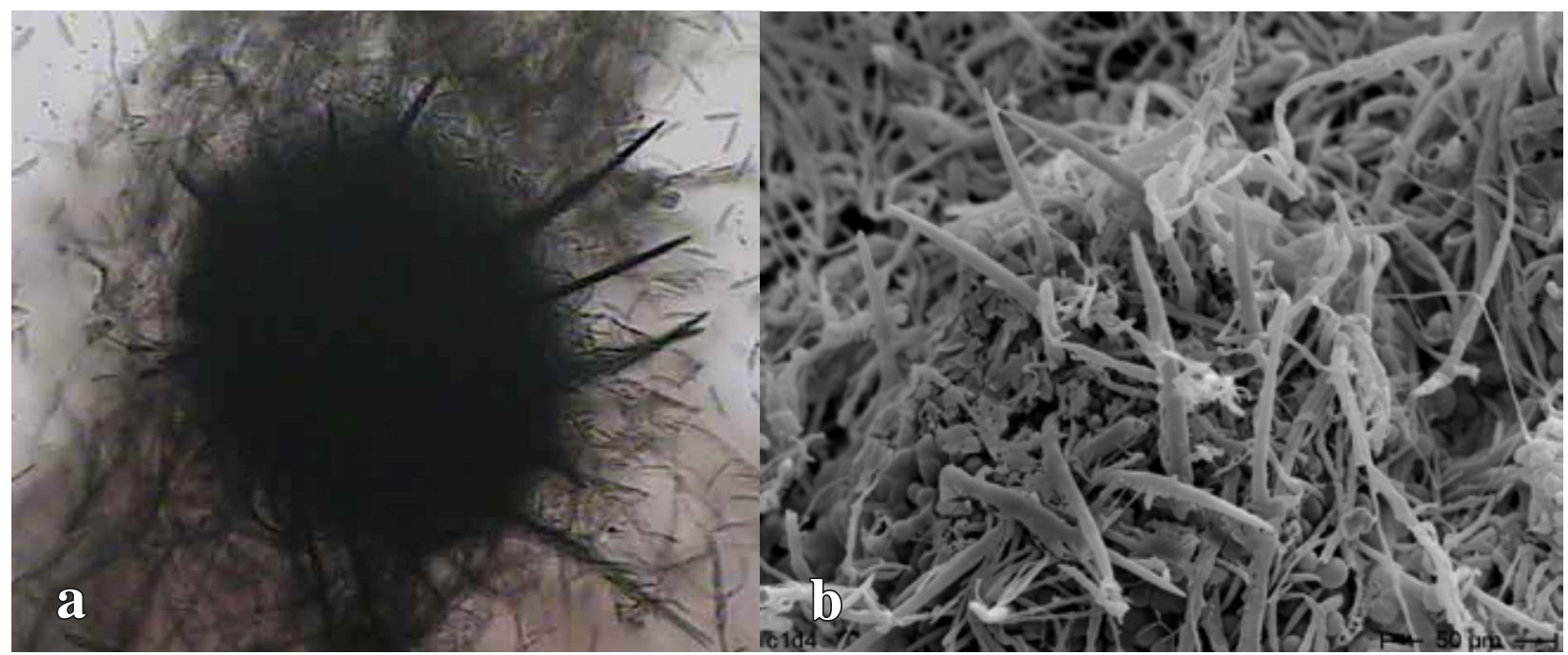

Fig. 2. C. dematium - acervuli x 125 (a) - photo E. Zalewska, acervuli with setoses - SEM (b) - photo M. Wróbel 


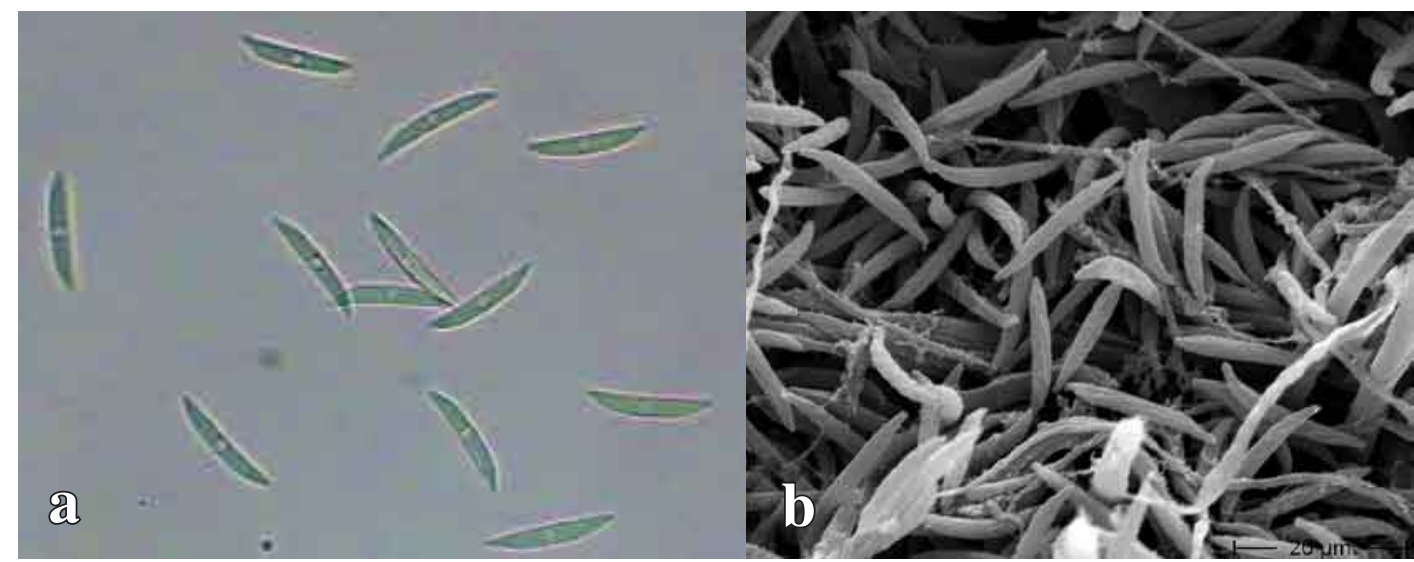

Fig. 3. C. dematium - conidia x 500 (a) - photo E. Zalewska, SEM (b) - photo M. Wróbel

\section{RESULTS}

As a result of the effect of post-culture liquids of $C$. dematium, isolates from 25 to $30 \%$ of caraway schizocarps did not germinate (Table 1). The mean number of schizocarps (mean of 5 replications) that did not germinate was from 5 to 6 , independently of the isolate. These data did not differ significantly from the data of the control combination (Table 2). On the other hand, the mean number of germinated schizocarps was from 14 to 15, depending on the isolate and these data were significantly higher in comparison with the control combination (Table 2). The necrosis of the germs was observed in all germinated schizocarps, and their mean number was 15.0, 14.4 and 14. 0, respectively for isolates K 625, K 426, K 425 (Table 2). These data were significantly higher than in the control combination (Table 2). The necrosis of all germs was observed on the third day of observation and it intensified with time (Fig. 4). Moreover, the growth of the germs of schizocarps which were in contact with the post-culture liquid of K 426 isolate was strongly inhibited and even they were totally necrotized in comparison with the germs treated with post-culture liquids of the last two isolates (Fig. 4). In the control combination, the necrosis of germs occurred sporadically and C. dematium was not isolated from these germs. The cultures of $C$. dematium with the macroscopic and microscopic features corresponding to those of the cultures used for artificial infection were isolated from the decayed schizocarps and schizocarps that did not germinate (Table 2).

In contact with the water suspension of $C$. dematium conidia, the percentage of schizocarps that did not germinate was 20,19 and 27, respectively for isolates K 625, K 425, and K 426 (Table 3). The mean number of not germinated schizocarps varied from 3.8 to 5.2, depending on the isolate, while in the control combination it was 3.0. There were no significant differences between these data (Table 4). The percentage of germinated schizocarps after artificial infection of water suspension of conidia was from 73 to 81 after 9 days of inoculation, while $85 \%$ of schizocarps germinated in the control combination (Table 3). The germs of schizocarps treated with water suspension of conidia isolates K 625 and K 425 showed necrosis in $14 \%$ of them, but $47 \%$ of the germs were decayed as a result of being treated with water suspension of conidia isolate K 426 (Table 3). The mean numbers of schizocarps with necrosis of germs were 2.8, 2.8 and 9.4, respectively for isolates K $625, \mathrm{~K} 425$ and K 426 after application of water suspension of their conidia (Table 4). The data for the two first mentioned isolates were significantly lower in comparison with the control. On the other hand, the mean number of decayed germs was significantly higher after the application of water suspension of conidia strain K 426 than the data obtained after infection of K 625 and K 425 isolates conidia and higher than in the control combination (Table 4).

Reisolation of the fungus showed the presence of C. dematium in 58, 91 and $99 \%$ of schizocarps after infection with water suspension of isolates K 625 , K 425 and K 426 conidia, respectively. C. dematium was not isolated from the plant material of the control combination.

The growth of caraway germs was inhibited in the experiment of artificial infection with water suspension of conidia and their roots were strongly reduced in comparison with the control combination (Fig. 5). The germs were from 0.5 to $1.0 \mathrm{~cm}$ in length in the experimental combination and to $5.0 \mathrm{~cm}$ long in the control (Fig. 5). Moreover, necrosis of the germs in infection combination was on 10 to $90 \%$ of their surface. No etiological signs, i.e. mycelium and acervuli occurred on decayed germs but such signs were observed on not germinated schizocarps. Moreover, the mass of conidia exudates was observed on the acervuli as clammy, thick, dark and shiny drops. On the other hand, necrosis of the germs did not occur in the control combination (Fig. 5). 


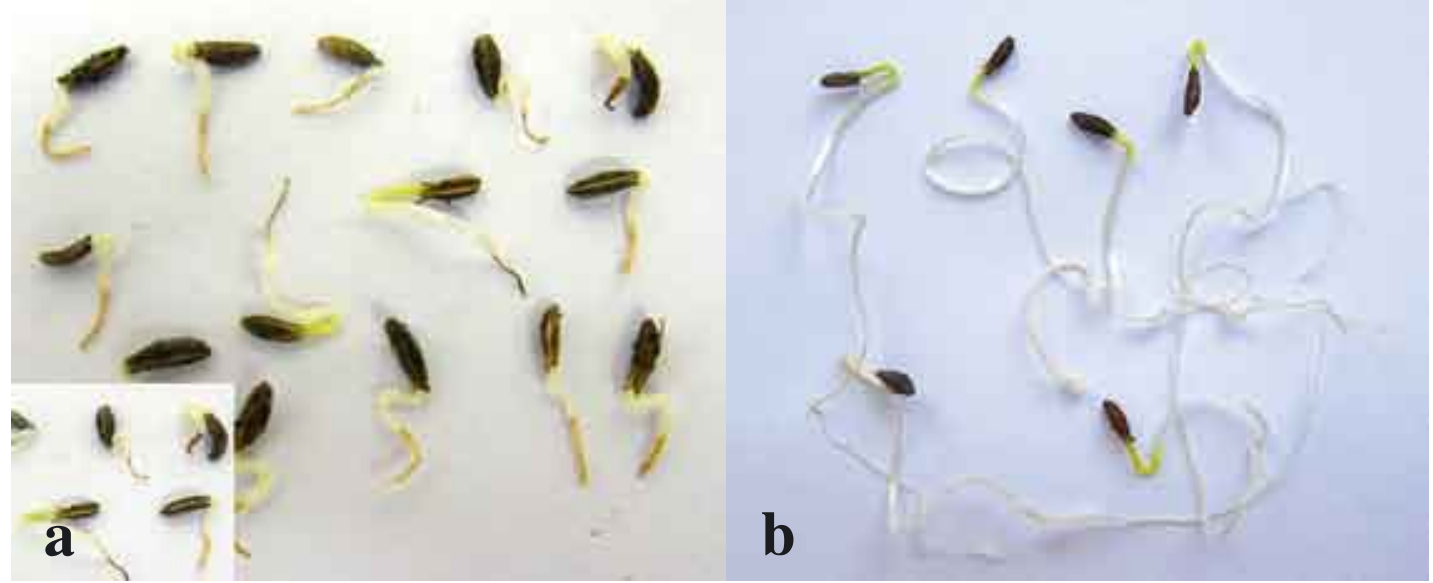

Fig. 4. Schizocarps of caraway after artificial infection with post-culture liquid of $C$. dematium: isolate $\mathrm{K} 426 \times 2$ (a), control x 1.5 (b) - photo E. Zalewska

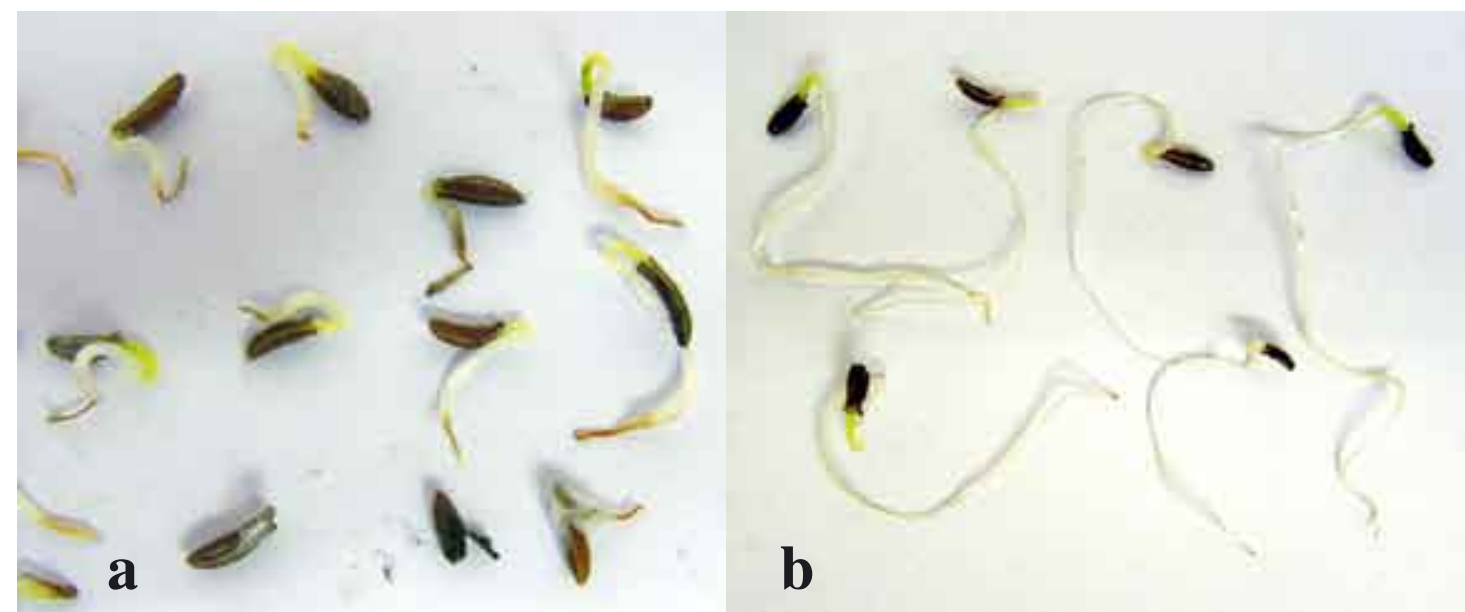

Fig. 5. Schizocarps of caraway after artificial infection with water suspension of $C$. dematium conidia: isolate $\mathrm{K} 426 \mathrm{x} 2$ (a), control x 1.5 (b) - photo E. Zalewska

Table1

Effect of inoculation with post-culture liquids of $C$. dematium on the germination of caraway (Carum carvi L.) schizocarps

\begin{tabular}{|c|c|c|c|c|c|}
\hline \multirow{3}{*}{ Isolate no. } & \multirow{3}{*}{$\begin{array}{c}\text { Number }=\% \text { examinated } \\
\text { schizocarps }\end{array}$} & \multicolumn{3}{|c|}{ Observation 9 days after infection } & \multirow{3}{*}{$\begin{array}{l}\text { Reisolation } \\
\text { of fungi }\end{array}$} \\
\hline & & \multirow{2}{*}{$\begin{array}{c}\text { Number }=\% \text { of } \\
\text { non-germinated } \\
\text { schizocarps }\end{array}$} & \multicolumn{2}{|c|}{ Number $=\%$ of germinated schizocarps } & \\
\hline & & & $\begin{array}{l}\text { Germs with } \\
\text { necrosis }\end{array}$ & $\begin{array}{l}\text { Germs without } \\
\text { necrosis }\end{array}$ & \\
\hline K 625 & 100 & 25 & 75 & 0 & 100 \\
\hline K 425 & 100 & 30 & 70 & 0 & 100 \\
\hline K 426 & 100 & 28 & 72 & 0 & 98 \\
\hline Control & 100 & 30 & 7 & 63 & 0 \\
\hline
\end{tabular}


Table 2

Effect of inoculation with post-culture liquids of $C$. dematium on the germination of caraway (Carum carvi L.) schizocarps (the mean of 5 replication)

\begin{tabular}{|c|c|c|c|c|c|}
\hline \multirow{3}{*}{ Isolate no. } & \multirow{3}{*}{$\begin{array}{c}\text { Mean number of } \\
\text { schizocarps examined }\end{array}$} & \multicolumn{3}{|c|}{ Observation 9 days after inoculation } & \multirow{3}{*}{$\begin{array}{l}\text { Reisolation } \\
\text { of pathogen }\end{array}$} \\
\hline & & \multirow{2}{*}{$\begin{array}{l}\text { Non- germinated } \\
\text { schizocarps }\end{array}$} & \multicolumn{2}{|c|}{ Germinated schizocarps } & \\
\hline & & & Germs with necrosis & $\begin{array}{l}\text { Germs without } \\
\text { necrosis }\end{array}$ & \\
\hline K 626 & 20 & $5.0 \mathrm{~b}$ & $15.0 \mathrm{c}$ & $0 \mathrm{a}$ & 20 \\
\hline K 425 & 20 & $6.0 \mathrm{~b}$ & $14.0 \mathrm{c}$ & $0 \mathrm{a}$ & 20 \\
\hline K 426 & 20 & $5.6 \mathrm{~b}$ & $14.4 \mathrm{c}$ & $0 \mathrm{a}$ & 19.6 \\
\hline Control & 20 & $6.0 \mathrm{~b}$ & $1.4 \mathrm{a}$ & $12.6 \mathrm{c}$ & 0 \\
\hline \multicolumn{6}{|c|}{$\mathrm{LSD}=3.2696$} \\
\hline \multicolumn{6}{|c|}{ Values marked with the same letter do not differ significantly } \\
\hline \multicolumn{6}{|c|}{ Table 3} \\
\hline \multicolumn{6}{|c|}{ Effect of inoculation with water suspension of $C$. dematium conidia on the germination of caraway (Carum carvi L.) schizocarp } \\
\hline \multirow{3}{*}{ Isolate no. } & \multirow{3}{*}{$\begin{array}{l}\text { Number }=\% \\
\text { examinated } \\
\text { schizocarps }\end{array}$} & \multicolumn{3}{|c|}{ Observation 9 days after inoculation } & \multirow{3}{*}{$\begin{array}{l}\text { Reisolation of } \\
\text { fungi }\end{array}$} \\
\hline & & \multirow{2}{*}{$\begin{array}{c}\text { Number }=\% \text { of } \\
\text { non-germinated } \\
\text { schizocarps }\end{array}$} & \multicolumn{2}{|c|}{ Number $=\%$ of germinated schizocarps } & \\
\hline & & & Germs with necrosis & $\begin{array}{l}\text { Germs without } \\
\text { necrosis }\end{array}$ & \\
\hline K 625 & 100 & 20 & 14 & 66 & 58 \\
\hline K 425 & 100 & 19 & 14 & 67 & 91 \\
\hline K 426 & 100 & 27 & 47 & 26 & 99 \\
\hline Control & 100 & 15 & 3 & 82 & 0 \\
\hline
\end{tabular}

Table 4

Effect of inoculation with water suspension of $C$. dematium conidia on the germination of caraway (Carum carvi L.) schizocarps (the mean of 5 replication)

\begin{tabular}{|c|c|c|c|c|c|}
\hline \multirow{3}{*}{ Isolate no. } & \multirow{3}{*}{$\begin{array}{l}\text { Mean number } \\
\text { of schizocarps } \\
\text { examined }\end{array}$} & \multicolumn{3}{|c|}{ Observation 9 days after inoculation } & \multirow{3}{*}{$\begin{array}{c}\text { Reisolation of } \\
\text { pathogen }\end{array}$} \\
\hline & & \multirow{2}{*}{$\begin{array}{c}\text { Non- germinated } \\
\text { schizocarps }\end{array}$} & \multicolumn{2}{|c|}{ Germinated schizocarps } & \\
\hline & & & $\begin{array}{c}\text { Germs with } \\
\text { necrosis }\end{array}$ & $\begin{array}{l}\text { Germs without } \\
\text { necrosis }\end{array}$ & \\
\hline K 626 & 20 & $4.0 \mathrm{a}$ & $2.8 \mathrm{a}$ & $13.3 \mathrm{~cd}$ & 11.6 \\
\hline K 425 & 20 & $3.8 \mathrm{a}$ & $2.8 \mathrm{a}$ & $13.4 \mathrm{~cd}$ & 18.2 \\
\hline K 426 & 20 & $5.2 \mathrm{ab}$ & $9.4 \mathrm{bc}$ & $5.4 \mathrm{ab}$ & 18.8 \\
\hline Control & 20 & $3.0 \mathrm{a}$ & $0.6 \mathrm{a}$ & $17.0 \mathrm{~d}$ & 0 \\
\hline
\end{tabular}

$\mathrm{LSD}=5.1008$

Values marked with the same letter do not differ significantly 
The first emerged plants in nodal phase were observed after 10 day of cultivation in the studies on the effect of $C$. dematium on emergencies and health of caraway seedlings using the method with infested soil; however, after 14 and 21 days the development of plants was observed. After 21days of observation, the obtained plants emerged from $87 \%$ of schizocarps as a result of artificial infection and from $98.6 \%$ of schizocarps in the control combination. Emergences of plants in the combination with artificial infection were very strongly inhibited in growth, because their size was from 4 to $7 \mathrm{~mm}$ and, moreover, they decayed rapidly as a result of pre- and post- emergence damping off (Fig. $6 \mathrm{a}, \mathrm{b}, \mathrm{c})$. Acervuli of the pathogen occurred in the germs if such plants (Fig. 6c). On the other hand, in the control combination, the seedlings were healthy and high for $13 \mathrm{~cm}$, and their roots were long for $15 \mathrm{~cm}$ (Fig. 6d).

The statistical analysis showed that the effect of artificial infection of plants through the infected soil was significantly higher compared with the control (Table 5). The mycological analysis of not germinated schizocarps and of seedlings with the necrosic symptoms showed the occurrence of $C$. dematium in their tissues; moreover, the reisolation of fungi confirmed it, and the fungus was not isolated from the control plants.

As a result of the studies on the effect of $C$. dematium on emergencies and healthiness of caraway seedlings by infection of solidified culture medium plaster overgrown with the fungus mycelium, seedlings from 98\% of germinating schizocarps were obtained after 14 days of observation, like in the control combination (Table 6). The plants were macroscopically healthy and reached the height of approximately $8 \mathrm{~cm}$. Only three plants were totally necrotic in combination with the artificial infection of $C$. dematium and the growth of two plants was inhibited. The cultures of $C$. dematium were isolated from these plants. All the other plants looked healthy, their aboveground parts and roots were well developed and lesions were not observed. However, the cultures of $C$. dematium were isolated from them (Tab. 6, Fig. 7). The growth of control plants was correct, the plants were healthy without any lesions and the pathogen was not isolated from them (Table 6, Fig. 7c).

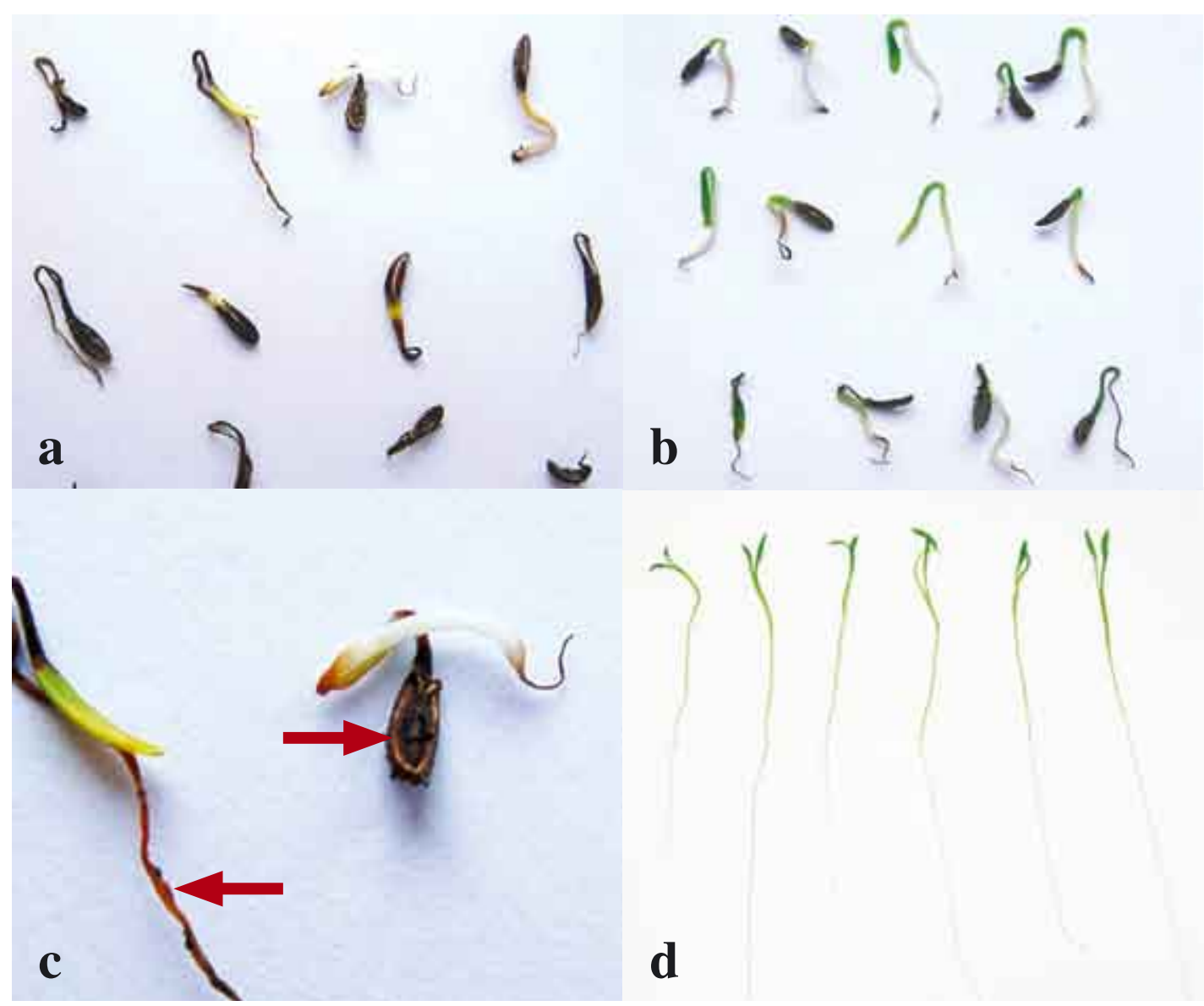

Fig. 6. Caraway plants after artificial infection of C. dematium - strain K 426 with an infested soil: germs taken from infested soil (Noll`s method) - pre-emergence damping off x 2 (a), post-emergence damping off $x 2$ (b), root and schizocarp of caraway covered with an acervuli of fungus x 4 (c), control (d) - photo E. Zalewska 


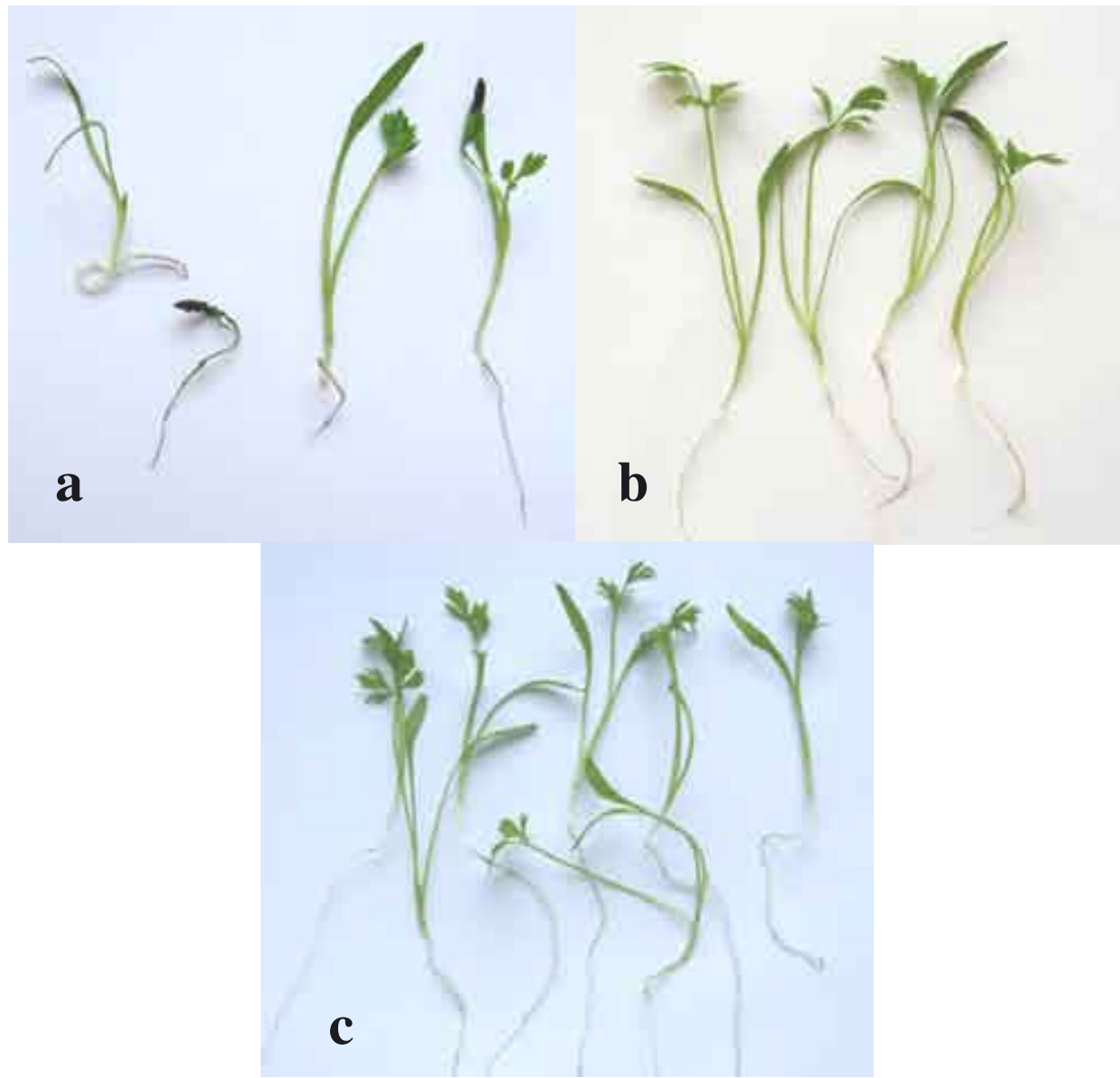

Fig. 7. Caraway plant growing on plaster of medium overgrown by $C$. dematium colony - strain K 426: plants taken off culture medium (a, b), control (c ) - photo E. Zalewska

Table 5

Effect of infection with $C$. dematium per infested soil on the shooting up of caraway (Carum carvi L.) - the mean of 5 replication

\begin{tabular}{|c|c|c|c|c|c|c|}
\hline \multirow[b]{2}{*}{ Isolate no. } & \multirow[b]{2}{*}{ Replication } & \multirow{2}{*}{$\begin{array}{c}\text { Number } \\
\text { of infected } \\
\text { schizocarps }\end{array}$} & \multirow{2}{*}{$\begin{array}{l}\text { Non-germinated } \\
\text { schizocarps }\end{array}$} & \multicolumn{2}{|c|}{ Number $=\%$ of emergences } & \multirow{2}{*}{$\begin{array}{c}\text { Reisolation of } \\
\text { pathogen }\end{array}$} \\
\hline & & & & $\begin{array}{l}\text { Seedlings with } \\
\text { necrosis }\end{array}$ & $\begin{array}{c}\text { Seedlings } \\
\text { without necrosis }\end{array}$ & \\
\hline \multirow{5}{*}{ K 426} & a & 20 & 3 & $17(85)$ & 0 & \multirow{5}{*}{$\begin{array}{c}\text { 81colonies from } \\
\text { stems }\end{array}$} \\
\hline & $\mathrm{b}$ & 20 & 4 & $16(80)$ & 0 & \\
\hline & $\mathrm{c}$ & 20 & 3 & $17(85)$ & 0 & \\
\hline & $\mathrm{d}$ & 20 & 1 & $19(95)$ & 0 & \\
\hline & e & 20 & 2 & $18(90)$ & 0 & \\
\hline Mean & & 20 & $2.6 \mathrm{~b}$ & $17.4 \mathrm{c}$ & $0 \mathrm{a}$ & \\
\hline \multirow{7}{*}{ Control } & a & 20 & 2 & $0(0)$ & $18(90)$ & \\
\hline & $\mathrm{b}$ & 20 & 1 & $0(0)$ & $19(95)$ & \\
\hline & $\mathrm{c}$ & 20 & 3 & $1(5)$ & $18(90)$ & \\
\hline & $\mathrm{d}$ & 20 & 1 & $0(0)$ & $19(95)$ & \\
\hline & $\mathrm{e}$ & 20 & 0 & $0(0)$ & $20(100)$ & \\
\hline & & 20 & $1.4 \mathrm{ab}$ & $0.2 \mathrm{a}$ & $18.6 \mathrm{c}$ & \\
\hline & & & \multicolumn{4}{|c|}{$\mathrm{LSD}=1.8552$} \\
\hline
\end{tabular}

Values marked with the same letter do not differ significantly 
Table 6

Effect of infection with plaster of $C$. dematium colony on the shooting up of caraway (Carum carvi L.) - the mean of 5 replication

\begin{tabular}{|c|c|c|c|c|c|c|}
\hline \multirow[b]{2}{*}{ Isolate no. } & \multirow[b]{2}{*}{ Replication } & \multirow{2}{*}{$\begin{array}{c}\text { Number } \\
\text { of infected } \\
\text { schizocarps }\end{array}$} & \multirow{2}{*}{$\begin{array}{l}\text { Non-germinated } \\
\text { schizocarps }\end{array}$} & \multicolumn{2}{|c|}{ Number (\%) of seedlings } & \multirow{2}{*}{$\begin{array}{l}\text { Reisolation of } \\
\text { pathogen }\end{array}$} \\
\hline & & & & $\begin{array}{l}\text { with necrosis of } \\
\text { germs }\end{array}$ & $\begin{array}{l}\text { without necrosis } \\
\text { of germs }\end{array}$ & \\
\hline \multirow{5}{*}{ K 426} & $\mathrm{a}$ & 20 & 0 & 1 & $20(100)$ & \multirow{5}{*}{$\begin{array}{l}40 \text { cultures from } \\
\text { stems and } 38 \\
\text { from the base of } \\
\text { stems }\end{array}$} \\
\hline & $\mathrm{b}$ & 20 & 0 & 0 & $20(100)$ & \\
\hline & $\mathrm{c}$ & 20 & 1 & 1 & $19(95)$ & \\
\hline & $\mathrm{d}$ & 20 & 0 & 1 & $20(100)$ & \\
\hline & $\mathrm{e}$ & 20 & 1 & 0 & $19(95)$ & \\
\hline Mean & & 20 & 0.4 & 0.6 & 19.6 & \\
\hline \multirow{6}{*}{ Control } & $\mathrm{a}$ & 20 & 1 & 0 & $19(95)$ & \\
\hline & $\mathrm{b}$ & 20 & 0 & 0 & $20(100)$ & \\
\hline & $\mathrm{c}$ & 20 & 1 & 0 & $19(95)$ & \\
\hline & d & 20 & 0 & 0 & $20(100)$ & \\
\hline & $\mathrm{e}$ & 20 & 0 & 0 & $20(100)$ & \\
\hline & & 20 & 0.4 & 0 & 19.6 & \\
\hline
\end{tabular}

\section{DISCUSSION}

Pathogenicity tests showed the possibility of harmfulness of the studied $C$. dematium isolates to caraway, especially in the first phases of plants' development. The harmfulness consisted of inhibiting the germination of schizocarps and emergences, necrosis of germs, pre- and post- emergence damping off germs and even as a decay of seedlings. All tested isolates of the fungus should be recognized as pathogenic to caraway because strong inhibition of schizocarps germination and necrosis of caraway germs were caused by them. Obtaining of a large number of germs with necrosis as a result of schizocarps infection using water suspension of conidia and damping off emergences as well as a result of sowing schizocarps into infested soil, one can suppose that the plants are susceptible to C. dematium, especially when they have had a direct contact with the pathogen from the very first phases of their growth, i.e. from germination. It seems that the presence of conidia in the infection material is very important for the positive result of infection. Pathogenicity tests of $C$. dematium to other species of plants which were conducted in USA, in Florida, Japan and Australia showed their strong infection as a result of using a suspension the pathogen`s conidia ( $\mathrm{C} \mathrm{e} \mathrm{r} \mathrm{k} \mathrm{a} \mathrm{u} \mathrm{-}$ skas and McDonald, 1991; McMillan and Grave s, 1996; S a to et al. 2005; W a s hington et al. 2006). Similarly, the suspension of the studied pathogen conidia was very effective in pathogenicity tests conducted in Japan for beech seedlings and in Bangladesh for soybean seeds ( $\mathrm{S}$ a h a s h i et al. 1995; Shovan et al. 2008).
The obtained results indicated the highest effect of the studied fungi isolates occurred after using the post-culture liquids of the pathogen. That effect resulted more probably owing to the presence of phytotoxic combinations in secondary metabolites of the fungus (Abou-Zaid et al. 1997; Mendiratta et al. 2005). Therefore, this method should be considered as a more useful method to study the pathogenicity of C. dematium to caraway, especially in a study of a large number of sowing materials. This method is used generally for the study of seeds and seedlings of other cultivated plants (M i s hra and B e hr, 1976; Ki e c an a and Kocyłak, 1999).

The studies showed that among the tested isolates of $C$. dematium, strain K426 was more aggressive and pathogenic, which fact can indicate differentiations intra $C$. dematium species.

The results of studies conducted in the laboratory and in a moisture chamber as well as frequent isolation of this fungus species from various organs of caraway (M a chowicz-S te faniak, 2010) makes it possible to recognize $C$. dematium as a potential pathogen of this plant. Pre- and post-emergence damping of young plants seems to be a more dangerous symptom of disease after their infection. The plants decayed in this way and the saprotrophic form of fungus moved to the soil environment with them (K o c h m a n, 1981). Therefore, the frequent cultivation in the same field conditions is very dangerous for a lot of agricultural and herbs plant as well. This method of cultivation could cause an increasing number of pathogens in the soil and in this way it can contribute to increased infection 
potential of the soil (G ä u m a n, 1959; K o c h m a n, 1981).

The occurrence of $C$. dematium was observed on the sowing material of various species of plants (Washington et al. 2006; Machowicz-Stef a n i ak, 2010), so this species could be transported with seeds. This fact indicated the necessity of obtaining the sowing material from healthy plants while fungicides should be used to treat schizocarps before the sowing.

\section{REFERENCES}

Abou-Zaid M., M. Dumas, D. Chauret, A. Watson and D. Thompson., 1997. C-methyl flavonols from the fungus Colletotrichum dematium $\mathrm{f}$. sp. epilobii. Phytochemistry, 45 (5): 957-961.

B e d l a n G ., 2005. Septoria carvi an Kümmel. Gemüse, 11:25.

Bobev S.G., Jelev Z.J., Zveibil A., Maymon M., Freeman S., 2009. First report of anthracnose caused by Colletotrichum dematium on statice Goniolimon tataricum synonym Limonium tataricum in Bulgaria. Plant Disease. 93 (5): 552.

Bonilla-Bernal T., Sandoval-Ramirez I., Estrada-Villardel G., Lopez M.O., 2003. Species of fungi found on Amarylidaceae. Fitosanidad. 7 (3): 13-16.

Cerkauskas R.F., McDonald M.R., 1991. First report of spinach anthracnose in Ontario. Plant Disease. 75 (1): 101.

Correll J.C., Morelock T.E., Black M.C., Koike S.T., Brandenberger L.P., Dainello F. J., 1994. Economically important diseases of spinach. Plant Disease. 78 (7): 653-660.

Evenhuis A., Verdam B., Gerlabh M., 1995. Studies on major diseases of caraway (Carum carvi L.) in the Netherlands. Industrial crops and Products. 4 (1): 53-61.

Farr D.F., Bills G.F., Chamuris G.P., Ross$\mathrm{m}$ an A.Y., 1995. Fungi on plant and plant products in the United States. APS Press the American Phytopatological Society. St. Paul, Minnesota USA: 1252.

Gabler J., Ehrig F., 1999. Phomopsis diachenii Sacc., ein gefährlicher Doldenbränne-Erreger an Kümmel - Erstnachweis für Deutschland. 2 Symposium Phytomedizin und Pflanzenschutz im Gartenbau, 27-30 Sept 1999, Wien: 149-151.

Gaüman E., 1959. Nauka o infekcyjnych chorobach roślin. Państwowe Wydawnictwo Rolne i Leśne, Warszawa: 748

Hong C., Chang P.F.L., Chang J.Y., Huang J.W., 2006. Identification for the causal agent of caspia anthracnose and its pathogenicity tests. Plant Pathology Bulletin, 15 (4): 241-249.

Kiecana I, Kocyłak E., 1999. Pathogenicity of Fusarium spp. on oats seedlings (Avena sativa L.) Plant Breed Sci. 43 (1): 91-99.
Kochman J., 1981. Zarys mikologii dla fitopatologów. Wydawnictwo SGGW, Wasrzawa: 320.

Łacicowa B., 1964. Badania mikroflory materiału siewnego pszenicy uprawianej na obszarze woj. lubelskiego, uwzględniające szczególnie grzyby patogeniczne /A study on microflora of seed material of wheat grown in the Lubelskie Voivodship (region) area, with special attention to pathogenic fungi. Ann. Uviv. Mariae CurieSklodowska sect. E, 19:381-406.

Łacicowa B., Kiecana I., Pięta D., 1992. Mikroflora nasion Bellis perennis i Celosia cristata. /Microflora of Bellis perennis and Celosia cristata seeds. Acta Mycol. 27(1): 41-48.

Machowicz-Stefaniak Z., 2010. Occurrence and characterization of Colletotrichum dematium (Fr.) Grove [in press].

Machowicz-Stefaniak Z., Zalewska E., 2008. Biodiversity of fungi colonizing different parts of caraway (Carum carvi L.). Electronic Journal of Polish Agricultural Universities. Horticulture. 11, (1).

Machowicz-Stefaniak Z., Zalewska E., 2004. Grzyby zagrażające uprawie wybranych ziół z rodziny Apiaceae w południowo-wschodniej Polsce. /The fungi threaten to some species of herbs from Apiaceae family cultivated in south-east Poland. Folia Univ. Agric. Stetin. Agricultura. 239 (95): 223-228.

Machowicz-Stefaniak Z., Zalewska E., 2000. Grzyby występujące na nadziemnych organach leszczyny./ The fungi colonizing above ground parts of hazel. [In:] Monitoring grzybów, Sekcja mikologiczna PTB. Red. M. Lisiewska, M. Ławrynowicz. Polskie Towarzystwo Botaniczne, Poznań-Łódź 2000: 153-166.

Machowicz-StefaniakZ., Gabler J., Zalewska E., 2003. Patogeny zagrażające uprawie roślin zielarskich./ The pathogens threaten the herbs cultivation. Folia Horticulturae, Suplement 2003/1: 565-567.

Machowicz-Stefaniak Z., Zimowska B., Zalewska E., 2008. The occurrence and pathogenicity of Phoma exigua Desm. var. exigua for selected species of herbs. Acta Agrobot. 61 (2): 157-166.

Mańka M., 1989. Taksonomia a fitopatologiczne funkcje saprobiotycznych grzybów glebowych środowiska leśnego./Taxonomy and phytopathological functions of saprobiotic soil fungi of forest environment. Zeszyty Naukowe AR Kraków, 348: 111-117.

McMillan R.T., Graves W.R., 1996. Periwinkle twig blight caused by Colletotrichum dematium on Catharanthus roseus L. Proc. Fla. State Hort. Soc. 109: 19-20.

Mendiratta D.K., Thamke D., Shukla A.K., Narang P., 2005. Keratitis due to Colletotrichum dematium - a case report. Indian J. Medical Microbiol. 23 (1): 56-58.

Mishra C.B.P., B ehr L., 1976. Der Einfluss von Kulturfiltraten von Fusarium culmorum (W.G.Sm.) Sacc. Fusarium avenaceum (Fr.) Sacc. und Fusarium nivale (Fr.) Ces. Griphosphaeria nivalis Müller et v. Arx auf 
die Keimung des Weizen. Arch. Phtopathol. Pflanzenschutz. 12: 373-377.

Odstrčilová L. Ondŕej M. Kocourková B. R ů ž i č k ová G ., 2002. Monitoring of incidence and determination of fungi on caraway, fennel, coriander and anise. Consideration of diseases importance and possibility of chemical protection. Proc. $6^{\text {th }}$ Conf. EFPP, Praha. Plant Protect Sci 38 (Special Issue 2): 340-343.

Padghan P.R., Belge B.A., 2009. Biological and chemical management of fruit rot of chilli caused by Colletotrichum dematium (P.) D. Green Farming. 2 (6): 388-390.

Sahashi N., Kubono T., Shoji T., 1995. Pathogenicity of Colletotrichum dematium isolated from current-year beech seedlings exhibiting damping-off. European J. Forest Pathol. 25 (3): 145-151.

Sato T., Taturo M., Yukihisa I., Hidenobu N., Jouji M., Yukio Y., 2005. Anthracnose of Japanese radish caused by Colletotrichum dematium. J. Gen. Plant Pathol. 71: 380-383.

Shinde S.S., Raut J.G., Rathod R.R., 2003. Effect of temperature, light and nutrient on growth and sporulation of Colletotrichum dematium L. Ann. Plant Physiol. 17 (2): 209-210.

Shovan L.R., Bhuiyan M.K.A., Sultana N., Begum J.A., Pervez Z., 2008. Prevalence of fungi associated with soybean seeds and pathogenicity tests of the major seed-borne pathogens. Internat. J. Sustainable Crop Production. 3 (4): 24-33.

Sutton B.C., 1980. The Coelomycetes Fungi imperfecti with Pycnidia, Acervuli and Stromata. Comm. Mycol. Inst., Kew Surrey, England: 696.

Washington W.S., Irvine G., Aldaoud R., DeAlwis S., Edwards J. Pascoe I.G., 2006. First record of anthracnose of spinach caused by Colletotrichum dematium in Australia. Australasian Plant Pathol. 35 (1): 89-91.

Vinnere O., Fatehi J., Wright S.A.I., Gerhards on B ., 2002. The causal agent of anthracnose of Rhododendron in Sweden and Latvia. Mycological Research, 106 (1): 60-69.
Von Arx J.A., 1957. Die Arten der Gattung Colletotrichum Cda. Phytopathol. Z. 29: 413-468.

Yoshida S., Shirata A., 1999. Survival of Colletotrichum dematium in soil and infected mulberry leaves. Plant Disease. 83 (5): 465-468.

Zalewska E., 2008. Occurrence and characterization of Septoria carvi Syd. (Coelomycetes, Sphaeropsidales). Herba Polonica. 554 (1): 25-32.

\section{Patogeniczność Colletotrichum dematium (Fr.) Grove dla kminku zwyczajnego Carum carvi $\mathrm{L}$.}

\section{Streszczenie}

Celem pracy było określenie patogeniczności trzech izolatów Colletotrichum dematium dla kminku zwyczajnego. W warunkach laboratoryjnych określano oddziaływanie płynów pohodowlanych i wodnej zawiesiny zarodników grzyba na zdolność kiełkowania rozłupek kminku zwyczajnego. W komorze klimatyzacyjnej badano oddziaływanie $C$. dematium na wschody i zdrowotność siewek przy zastosowaniu metody infekcji przez zakażoną ziemię i przez plaster pożywki przerośnięty grzybnią patogenu. Badane izolaty grzyba uniemożliwiły kiełkowanie części testowanych rozłupek. Natomiast u skiełkowanych rozłupek wszystkie izolaty powodowały nekrozę kiełków i korzeni. Metodę infekcji za pomocą płynów pohodowlanych uznano za najodpowiedniejszą do szybkiej oceny patogeniczności $C$. dematium dla kminku zwyczajnego. Na podstawie pozytywnych wyników testów patogeniczności badane izolaty $C$. dematium uznano za patogeniczne dla kminku zwyczajnego. W związku z powyższym oraz z powtarzającą się częstą izolacją grzyba z różnych organów tej rośliny, $C$. dematium uznano za potencjalnie patogeniczny dla kminku zwyczajnego. 
